\title{
PENILAIAN PEMAHAMAN REPRESENTASI GRAFIK MATERI OPTIKA GEOMETRI MENGGUNAKAN TES DIAGNOSTIK
}

\author{
Wawan Bunawan ${ }^{\mathrm{a}}$, Agus Setiawan ${ }^{\mathrm{b}}$, Aloysius Ruslic, dan Nahadi ${ }^{\mathrm{b}}$ \\ ${ }^{\text {a }}$ FMIPA UNIMED, 'Sekolah Pascasarjana UPI, ' UNPAR \\ email:wanbunawan@gmail.com
}

\begin{abstract}
Abstrak: Tujuan penelitian adalah mengembangkan dan menerapkan tes diagnostik pilihan ganda tiga tingkat untuk mengukur pemahaman representasi grafik mahasiswa terkait esensi inkuiri sains dan materi optika geometri. Penelitian menggunakan metode campuran melibatkan 83 mahasiswa calon guru fisika di satu LPTK Sumatera Utara. Instrumen tes diagnostik terlebih dahulu didesain kemudian disempurnakan selama proses, direvisi, dan digunakan untuk mendeteksi dan menilai pemahaman representasi grafik mahasiswa calon guru fisika. Instrumen tes telah dikembangkan untuk dapat mendiagnosis dan memperbaiki kesalahan-kesalahan yang dilakukan calon guru fisika terkait dengan keterampilan mengonstruk grafik, menemukan kesulitan-kesulitan dalam membaca dan menginterpretasi grafik. Analisis data dilakukan secara kualitatif dan kuantitatif. Hasil studi menunjukkan pembacaan grafik dan keterampilan menginterpretasi grafik calon guru fisika masih belum memadai dan juga kemahiran dalam menganalisis grafik bergantung pada jenis grafik dan level atau tipe pertanyaan yang dikembangkan.
\end{abstract}

Kata Kunci: representasi grafik, optik geometri, diagnostik tes

\section{ASSESSING OF UNDERSTANDING GRAPHICAL REPRESENTATION CONTENT GEOMETRICAL OPTIC USING DIAGNOSTIC TEST}

\begin{abstract}
The purpose of this study is to develop and apply three tier multiple choice diagnostic test to measure student's understanding of graphical representation about essential features of inquiry and content geometrical optic. The study was conducted using mixed methods and carried out with 83 prephysics teachers at a University of Teachers Education in North Sumatera. The diagnostic instrument was designed and then progressively refined, revised, and implemented to detect and assess student's understanding of graphical representation. Test instrument was developed to diagnose and correct the mistakes made by pre-service physics teachers about construction graphic skills, difficulties in the reading and interpretation graphical representation. The results of this study showed that graph reading and interpretation skills of pre service teachers were inadequate and also their graphing analysis varies depending on the type of graph and level type of question was developed.
\end{abstract}

Keywords: graphical representation, geometrical optic, diagnostic test

\section{PENDAHULUAN}

Grafik merupakan salah satu kelompok representasi yang secara matematis digunakan sebagai alat atau sarana dalam berbagai disiplin ilmu untuk mengungkapkan atau memvisualisasikan pernyataan verbal yang kompleks. Grafik dapat divisualisasikan dalam bentuk dua tiga dimensi yang menghubungkan dua atau lebih variabel. Grafik sebagai ungkapan matematis penting atas pertimbangan dua alasan. Pertama, grafik dapat merepresentasikan atau meringkas- kan data dan kedua mengomunikasikan data agar mudah untuk dilakukan interpretasi. Program pembelajaran fisika harus membekalkan dan meningkatkan penguasaan keterampilan dalam bidang grafik untuk pengolahan data. Mahasiswa harus terampil membuat dan menginterpretasi grafik. Penggunaan grafik dalam proses penyelesaian masalah membutuhkan beberapa skill atau kemahiran seperti mampu memvisualisasikan solusi suatu masalah, meringkas data, menginterpretasi hubungan antar- 
berbagai variabel, membuat prediksi, dan menarik kesimpulan.

Representasi grafik dan simbolik dalam pendidikan fisika harus diberikan dan ditumbuhkan dalam setiap kesempatan proses pembelajaran fisika, baik di dalam kelas atau di laboratorium mengingat peranannya yang sangat penting. Grafik mampu menyajikan suatu konten secara nyata, meningkatkan pemahaman konsep dan hubungan dengan konsep lainnya, membangun kerangka konseptual dan meringkaskan bahan belajar (Kilic dkk, 2012). Pengetahuan atau kemampuan di bidang grafik merupakan salah satu keutamaan dalam keterampilan proses sains, di dalam keterampilan proses sains dasar grafik digunakan untuk menjelaskan dan menghubungkan ide-ide dan informasi sedangkan di dalam keterampilan proses sains terintergrasi grafik digunakan untuk menginterpretasi data, mengorganisir data dan menggambarkan kesimpulan.

Pengetahuan pemahaman tentang representasi grafik dikaitkan dengan pemahamannya secara matematis. Kemampuan representasi grafik merupakan keterampilan yang sangat penting, harus dapat mengonstruksi grafik berdasarkan kaidah aljabar atau formula tertentu, menyusun atau memformulasikan suatu persamaan berdasarkan suatu hubungan fungsional dari suatu grafik, menghubungkan informasi berdasarkan grafik dengan suatu formula dan menarik kesimpulan untuk menyelesaikan masalah berdasarkan grafik. Alkan dan Erdem (2011) mengatakan bahwa untuk menjelaskan data eksperimen yang terkumpul dan untuk mencapai kesimpulan yang spesifik perlu dilakukan pencatatan data secara teratur, mengklasifikasi dan mentransformasinya ke dalam grafik agar menjadi jelas hubungannya.

Proses belajar dengan menggunakan verbal dan representasi visual menghasilkan penyimpanan informasi yang lebih baik daripada hanya menggunakan pembelajaran verbal saja. Pembelajaran seperti ini menghasilkan pemahaman materi yang lebih baik dari pada hanya menggunakan satu representasi sederhana saja, pembelajar dapat memahami hakekat fenomena lebih baik pada saat belajar dengan mengguna- kan kombinasi teks dan gambar/grafik (Anagnostopoulou dkk, 2012). Ainsworth (1999) menegaskan ada tiga fungsi utama penggunaan multi representasi dalam pembelajaran yaitu saling melengkapi dalam proses dan informasi (complementary), mengkontrol interpretasi (constrain interpretation), dan mengkonstruk pemahaman mendalam (construct deeper understanding).

Membelajarkan mahasiswa calon guru fisika tentang bagaimana membaca, menginterpretasi dan mengonstruk grafik merupakan suatu topik pembelajaran yang penting dalam materi optika geometri. Kemampuan atau keterampilan representasi grafik membutuhkan pengetahuan tambahan dari disiplin ilmu matematis dan dapat digunakan untuk disiplin ilmu lainnya. Grafik memiliki peranan sebagai suatu alat visual untuk menunjukkan sekumpulan data dan merepresentasikan hubungan berbagai variabel yang kompleks dengan lebih efektif. Materi optika geometri memiliki banyak representasi grafik. Representasi grafik digunakan untuk menyatakan hubungan antara jarak objek dan jarak bayangan objek terhadap suatu cermin lengkung atau lensa, grafik hubungan antara perbesaran bayangan sebagai fungsi dari jarak objek, grafik hubungan antara sudut sinar datang dan sudut sinar bias pada pembiasan cahaya oleh suatu bahan optik.

Mendeteksi pengetahuan keterampilan representasi grafik bagi calon guru fisika sangat penting karena kelak seorang guru fisika akan efektif menggunakan representasi grafik dalam program dan pelaksanaan pembelajaran yang didesainnya yang diharapkan dapat meningkatkan pemahaman grafik para siswa yang diajarnya. Mendeteksi kesalahan-kesalahan dalam membaca, menginterpretasi dan mengkomunikasikan hubungan antar variabel dalam bentuk grafik dan mengkonstruksi grafik perlu dilakukan untuk calon guru fisika selama proses pembelajaran di perguruan tinggi untuk meningkatkan efektivitas pembelajaran.

Tes diagnostik untuk mengukur dan mendeteksi tingkat pemahaman dan kesulitan yang dialami pembelajar dalam penguasaan representasi grafik perlu dilakukan selama proses pem- 
belajaran dan hasil yang dicapainya. Organisation for Economic Co-operation and Development (OECD) (2006) mengembangkan suatu program asesmen dengan nama Programme for International Student Assessment (PISA). Butir soal tes PISA untuk setiap unit tesnya menggunakan butir soal yang menggabungkan materi soal dalam bentuk teks, gambar, tabel, grafik yang diikuti oleh pernyataan butir soal (comprising stimulus material consisting of text, images, tables, graphs followed by questions (test items) related with the stimulus material).

Penggunaan tes diagnostik dua tingkat (two tier) untuk mengases atau mengidentifikasi konsepsi ilmiah (scientific conceptions) yang ada di kalangan pelajar Taiwan telah dilakukan oleh Treagust \& Chandrasegaran (2007). Tan dkk (2005) menggunakan tes diagnostik dua tingkat untuk menentukan pemahaman konsep energi ionisasi dilakukan untuk pelajar di Singapura. Tsui dan Treagust (2010) menggunakan tes diagnostik dua tingkat untuk mengevaluasi argumen ilmiah dikalangan pelajar dalam bidang genetika. Wiji dkk (2014) menggunakan tes diagnostik dua tingkat untuk mengases model mental kimia sekolah mencakup lima masalah: stoichiometry, thermochemistry, chemical equilibrium, tingkat reaksi, dan asam-basa. Caleon dan Subramaniam (2010) telah mengembangkan dan menggunakan tes diagnostik tiga tingkat untuk mengases pemahaman konsep gelombang yang dimiliki pelajar di Singapura. Dindar dan Geban (2011) mengembangkan tes diagnostik tiga tingkat untuk mengases pemahaman konsep asam dan basa siswa sekolah menengah atas.

Hasil penelitian yang telah dilakukan oleh Alacaci dkk (2011) berkaitan dengan pemahaman grafik memperlihatkan mahasiswa calon guru sekolah dasar di Turkey dapat mengenali dengan benar penggunaan grafik batang, grafik bentuk pie, dan grafik berbentuk garis yang cocok digunakan untuk mengungkapkan fenomena tertentu, akan tetapi tidak dapat mengenali dengan benar penggunaan grafik pencar (scatter plot). Yavuz dan Egin (2010) menunjukkan hasil penelitian terkait dengan kemampuan siswa sekolah lanjutan atas untuk kelas penelitian mampu memperlihatkan penguasaan grafik, yaitu membuat grafik berdasarkan persamaan aljabar tertentu atau sebaliknya membuat persamaan aljabar berdasarkan suatu grafik karena seringnya berlatih, hal sebaliknya untuk kelas tradisional para siswa mengalami banyak kesulitan dan kesalahan. Sezen, dkk (2012) melaporkan hasil penelitiannya tentang kemampuan calon guru fisika mahasiswa pendidikan fisika Universitas Negeri Ankara di Turkey yang menunjukkan kemampuan menggambar grafik masih rendah demikian juga kemampuan membaca dan menginterpretasi grafik masih rendah. Mahasiswa tidak mahir menggunakan hubungan antara fungsi dengan grafik atau sebaliknya hubungan antara grafik dengan fungsi.

Pengetahuan inkuiri sains dan konten optika geometri memiliki banyak representasi grafik, representasi matematis dan representasi verbal. Jenis pengetahuan yang dilibatkan adalah pengetahuan konseptual dan pengetahuan prosedural terkait materi pembiasan dan pemantulan cahaya, cermin datar dan cermin lengkung, lensa konvergen dan divergen. Galili and Hazan (2000) menemukan miskonsepsi calon guru dan siswa sekolah menengah pada topik cahaya, pembentukan bayang-bayang, pemantulan dan pembiasan. Parker (2006) menunjukkan cara bagaimana meningkatkan penguasaan konten cahaya dan pembentukan bayangan yang dimiliki oleh guru IPA yang mengikuti pelatihan dalam meningkatkan pemahamannya dengan menggunakan konflik kognitif. Chang, dkk (2007) menyimpulkan adanya miskonsepsi yang dimiliki siswa sekolah lanjutan terkait pembentukan bayangan oleh lensa dan cermin. Buty dan Mortimer (2008) menemukan adanya kesulitan dalam melakukan pembelajaran optika di kelas pada bagian dialog selama proses interaksi pembelajaran.

Tujuan umum penelitian yang ingin dicapai adalah mengembangkan tes diagnostik pilihan ganda tiga tingkat yang dapat digunakan untuk mendeskripsikan kemampuan penguasaan representasi grafik calon guru fisika. Tujuan khusus dari penelitian ini adalah mendeteksi pengetahuan calon guru fisika terkait keteram- 
pilan penggunaan grafik dan menentukan kesulitan-kesulitan dalam membaca dan menginterpretasi grafik berdasarkan level fungsi grafik.

\section{METODE}

Metode yang dikembangkan dalam penelitian ini adalah mixed methods. Desain yang dipakai adalah Exploratory Design (Creswell \& Clark, 2007). Desain ini cocok digunakan dalam mengembangkan instrumen tes yang diawali dari metode penelitian kualitatif dan diikuti secara berurutan dengan metode kuantitatif dan menarik kesimpulan kualitatif berdasarkan data kuantitatif.

Subjek penelitian adalah mahasiswa S1 yang mengambil materi perkuliahan Optika Geometri pada semester berjalan terhitung mulai akhir Februari sampai dengan awal bulan April tahun 2013 yang melibatkan seluruh kelas (tiga kelas) berjumlah 83 orang mahasiswa. Tempat penelitian di salah satu LPTK jurusan pendidikan Fisika di Sumatera Utara. Kelas A digunakan sebagai kelas uji coba awal pengem- bangan di lapangan, kelas B sebagai kelas penelitian yang menggunakan pembelajaran berbasis inkuiri laboratorium, dan kelas $\mathrm{C}$ sebagai kelas bebas. Tiga kelas tersebut menggunakan instrumen tes diagnostik yang sama.

Hubungan antara pengembangan tes diagnostik tiga tingkat dengan butir soal tes representasi grafik dapat dilukiskan dalam Gambar 1. Konteks butir soal yang dikembangkan berbasis inkuiri laboratorium dan analisis interpretatif berdasarkan tampilan grafik. Butir soal representasi grafik adalah bagian dari butirbutir soal tes diagnostik.

Representasi grafik untuk materi dan esensi optika geometri dalam penelitian ini dibedakan menjadi tiga level. Batasan ketiga level grafik dapat diuraikan perbedaanya sebagai berikut.

Level 1 (L1): grafik merepresentasikan hubungan dua variabel fisis berdasarkan data eksperimen, atau bersumber dari data empirik representasi formula optika geometri yang memberikan visualisasi kuantitatif.

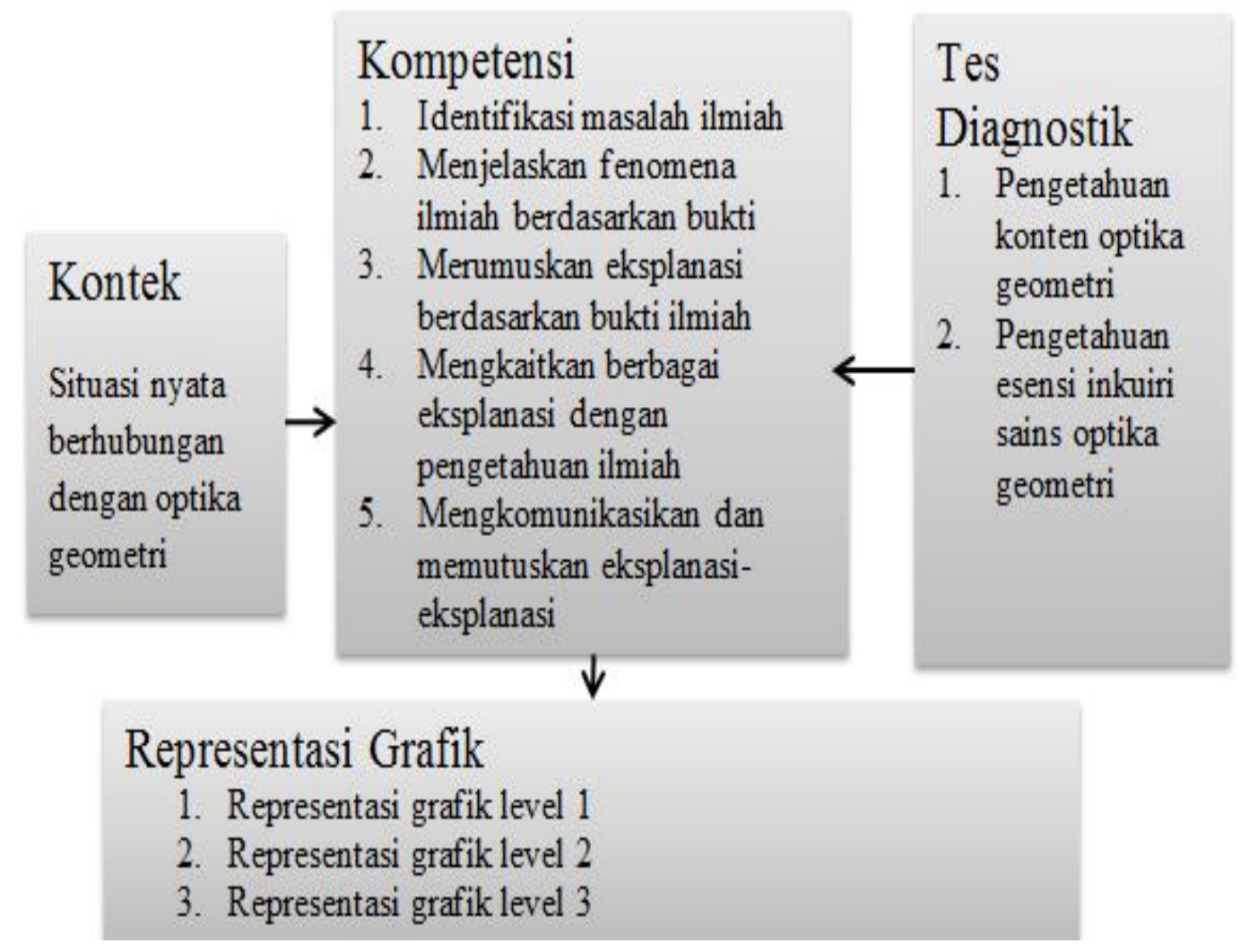

Gambar 1. Kerangka Pikir Pengembangan Butir Representasi Grafik 
Tabel 1. Tahapan Analisis Data

\begin{tabular}{lll}
\hline \multicolumn{1}{c}{ Data } & \multicolumn{1}{c}{ Sumber Data } & \multicolumn{1}{c}{ Analisis } \\
\hline $\begin{array}{l}\text { Konten materi optika } \\
\text { geometri }\end{array}$ & $\begin{array}{l}\text { Studi literatur, buku teks, buku } \\
\text { kuliah } \\
\text { Inkuiri sains yang } \\
\text { melekat pada materi } \\
\text { optika geometri } \\
\text { Bundel tes }\end{array}$ & $\begin{array}{l}\text { Kualitatif konsep-konsep esensial dan aplikasinya } \\
\text { teks, laporan penelitian }\end{array}$ \\
$\begin{array}{l}\text { Data hasil uji coba tes } \\
\text { Piloting }\end{array}$ & Hasil uji coba & $\begin{array}{l}\text { Kualitatif untuk membangkitkan pertanyaan- } \\
\text { pertanyaan inkuiri }\end{array}$ \\
$\begin{array}{l}\text { Implementasi Model } \\
\text { Tes }\end{array}$ & Data kuantitatif & $\begin{array}{l}\text { Kualitatif judmen ahli dan analisis kuantitatif } \\
\text { teknik korelasional antar skor validator }\end{array}$ \\
diagnostic & Kolektif tahapan tes diagnostik & $\begin{array}{l}\text { Kuantitatif dengan menggunakan program } \\
\text { ITEMAN, Microsoft excel, dan manual. } \\
\text { Analisis kuantitatif dan kualitatif validitas butir, } \\
\text { reliabilitas tes, daya beda, tingkat kesulitan. }\end{array}$ \\
\hline
\end{tabular}

Level 2 (L2): grafik merepresentasikan hubungan dua variabel fisis berdasarkan data eksperimen dan mengkaitkan sebagian informasi dari grafik dengan formula optika geometri. Pemecahan masalah untuk menjawab pertanyaan terkait data dapat diperoleh langsung dari grafik.

Level 3 (L3): grafik merepresentasikan hubungan dua variabel fisis berdasarkan data eksperimen dan mengkaitkan sebagian informasi dari grafik dengan formula optika geometri untuk menjawab pertanyaan diluar data yang ada dari grafik.

Pemahaman representasi grafik diartikan sebagai kemampuan peserta tes atau pembaca untuk menafsirkan makna berdasarkan informasi yang diperoleh dari grafik dan mengaitkan analisisnya berdasarkan konsep-konsep keilmuan optika geometri dan matematis. Berdasarkan level grafik dikembangkan tiga jenis kelompok pertanyaan dalam pengembangan butir soal tes diagnostik optika geometri. Level pertanyaan sederhana (mudah) adalah kelompok pertanyaan yang mengekstraksi langsung informasi berdasarkan data yang disajikan grafik, level pertanyaan menengah (sedang) yang membutuhkan pemahaman hubungan di antara data yang disajikan grafik, dan level pertanyaan kompleks (sulit) yang membutuhkan kemampuan ekstrapolasi dan interpolasi data dikaitkan dengan konsep dan formula yang berhubungan dengan konten optika geometri.
Level fungsi grafik ini digunakan untuk melakukan analisis kualitatif terhadap jawaban dan pilihan alasan yang dipilih oleh seluruh peserta tes. Level grafik fungsi menggambarkan kemampuan analisis yang dimiliki peserta tes. Analisis kuantitatif dilakukan dengan menggunakan program analisis butir soal (ITEMAN) versi 3.00. Analisis kuantitatif meliputi tingkat kemudahan butir soal, daya pembeda butir soal, keberfungsian pilihan pengecoh dan reliabilitas tes berdasarkan data empirik yang diperoleh dari lembar jawaban tes pilihan ganda.

Analisis kualitatif digunakan dalam mengembangkan tes diagnostik untuk tahap-tahap awal seperti melakukan analsisis terhadap konten materi optika geometri dan esensi inkuiri sains yang menyertai proses pembelajaran materi optika geometri. Analisis kualitatif lanjutan dilakukan untuk hasil validasi oleh para validator dan selama proses perbaikan butir soal hasil uji coba. Analisis kuantitatif dilakukan untuk menentukan karakteristik butir soal dan tes yang berkaitan dengan data empirik yang digunakan selama mengembangkan tes. Tahapan analisis data diberikan pada Tabel 1 .

\section{HASIL DAN PEMBAHASAN}

Tiga puluh butir soal pilihan ganda tiga tingkat tes diagnostik telah dikembangkan untuk mengevaluasi dan mendeteksi kemampuan mahasiswa dalam menggambarkan dan menerapkan lima keterampilan esensial proses sains 
dalam materi optika geometri. Dua puluh butir soal tes dignostik tiga tingkat telah dikembangkan untuk mendeteksi dan mengevaluasi kemampuan mahasiswa dalam memperoleh penguasaan materi optika geometri. Indeks reliabilitas internal alpha tes diagnostik adalah 0,79 untuk tes konten optika geometri, dan indeks reliabilitas alpha untuk tes inkuiri sebesar 0,86 . Tingkat kemudahan butir (TK) soal memiliki rentang indeks dari 0,21 sampai dengan 0,89, sedangkan rentang indeks daya pembeda (DP) butir soal dari 0,20 sampai 1,00 .

Validasi butir soal dilakukan oleh dua orang dosen bidang studi (VLDR 1 dan VLDR 2) yang terkait dengan konten dan esensi inkuiri sains optika geometri dan satu orang dosen dari sisi pendidikan (VLDR 3). Masing-masing validator dimohon untuk memberikan validasi ter- hadap konstruksi soal, dan konten soal. Teknik yang dikembangkan untuk memvalidasi digunakan metode penskoran dan komentar kualitatif terhadap konten materi, esensi inkuiri, pernyataan soal, pilihan jawaban, pilihan alasan, indikator yang dikembangkan, dan dari konstruksi soal.

Analisis korelasional memperlihatkan bahwa perangkat tes diagnostik untuk mendeteksi pengetahuan esensi inkuiri sains optika geometri telah menunjukkan validitas yang baik ditinjau dari sisi konten esensi inkuiri dan pedagogi berdasarkan penilaian yang diberikan validator. Korelasi yang tinggi juga ditunjukkan oleh dua orang validator bidang studi dengan koefisien korelasi yang memperlihatkan bahwa butir-butir soalnya telah menunjukkan validitas isi yang baik.

Tabel 2. Korelasi Nonparametrik Validasi Soal Esensi Inkuiri

\begin{tabular}{|c|c|c|c|c|c|}
\hline \multicolumn{3}{|c|}{ Analisis Korelasi } & \multirow{2}{*}{$\begin{array}{r}\begin{array}{l}\text { Validator 1 } \\
\text { (VLDR1) }\end{array} \\
1.000\end{array}$} & \multirow{2}{*}{$\begin{array}{c}\begin{array}{l}\text { Validator } 2 \\
(\text { VLDR2) }\end{array} \\
.707(* *)\end{array}$} & \multirow{2}{*}{$\begin{array}{c}\begin{array}{c}\text { Validator } 3 \\
(\text { VLDR3) }\end{array} \\
.816(* *)\end{array}$} \\
\hline Kendall's & VLDR1 & Correlation Coefficient & & & \\
\hline & & Sig. (2-tailed) & . & .000 & .000 \\
\hline & & $\mathrm{N}$ & 30 & 30 & 30 \\
\hline & VLDR2 & Correlation Coefficient & $.707(* *)$ & 1.000 & $.722(* *)$ \\
\hline & & Sig. (2-tailed) & .000 & . & .000 \\
\hline & & $\mathrm{N}$ & 30 & 30 & 30 \\
\hline & VLDR3 & Correlation Coefficient & $.816(* *)$ & $.722(* *)$ & 1.000 \\
\hline & & Sig. (2-tailed) & .000 & .000 & \\
\hline & & $\mathrm{N}$ & 30 & 30 & 30 \\
\hline
\end{tabular}

** Correlation is significant at the 0.01 level (2-tailed).

Tabel 3. Korelasi Nonparametrik Validasi Konten

\begin{tabular}{|c|c|c|c|c|}
\hline \multicolumn{3}{|c|}{ Analisis Korelasi } & \multirow{2}{*}{$\begin{array}{r}\begin{array}{r}\text { Validator2 } \\
\text { (VLDR1) }\end{array} \\
1.000\end{array}$} & \multirow{2}{*}{$\begin{array}{r}\begin{array}{r}\text { Validator } 3 \\
\text { (VLDR2) }\end{array} \\
.728(* *)\end{array}$} \\
\hline \multirow{6}{*}{$\begin{array}{l}\text { Kendall's } \\
\text { tau_b }\end{array}$} & VLDR2 & Correlation Coefficient & & \\
\hline & & Sig. (2-tailed) & & .000 \\
\hline & & $\mathrm{N}$ & 20 & 20 \\
\hline & VLDR3 & Correlation Coefficient & $.728(* *)$ & 1.000 \\
\hline & & Sig. (2-tailed) & .000 & . \\
\hline & & $\mathrm{N}$ & 20 & 20 \\
\hline
\end{tabular}

** Correlation is significant at the 0.01 level (2-tailed). 
1. Obyek ditempatkan pada pusat lensa, kemudian digerakkan menjauhi lensa sepanjang sumbu utamanya sambil diukur jarak bayangan $i$. Grafik menyatakan hubungan jarak bayangan $i$ terhadap jarak obyek $p$ sampai $p_{s}=$ $60 \mathrm{~cm}$. Berapakah jarak bayangan saat $p=100 \mathrm{~cm}$ ?
a. $-30 \mathrm{~cm}$
b. $30 \mathrm{~cm}$
c. $-43 \mathrm{~cm}$
d. $43 \mathrm{~cm}^{*}$

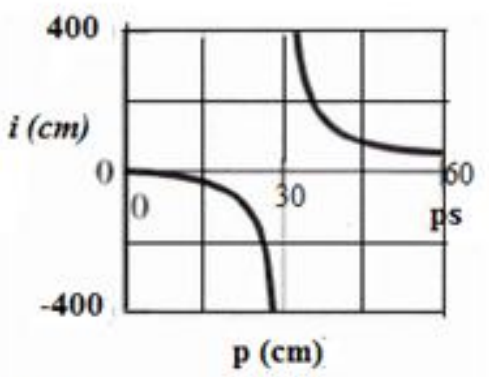

Alasan memilih jawaban:

a. Saat $p=30 \mathrm{~cm}$ diperoleh panjang fokus lensa $30 \mathrm{~cm}$.**

b. Saat $p=30 \mathrm{~cm}$ diperoleh panjang fokus lensa $-30 \mathrm{~cm}$

c. Saat $p=30 \mathrm{~cm}$ diperoleh panjang fokus lensa $40 \mathrm{~cm}$

d. Saat $p=30 \mathrm{~cm}$ diperoleh panjang fokus lensa $-40 \mathrm{~cm}$.

Pilih skala keyakinan kebenaran terhadap pilihan jawaban dan alasan

$\begin{array}{llllll}\mathbf{1} & \mathbf{2} & \mathbf{3} & \mathbf{4} & \mathbf{5} & \mathbf{6} \\ \text { Ditebak } & \text { hampir } & \text { tidak } & \text { hampir } & \text { Yakin } & \text { Sangat } \\ & \text { ditebak } & \text { yakin } & \text { yakin } & & \text { yakin }\end{array}$

$*, * *$, kunci jawaban dan alasan

Gambar 2. Contoh Butir Soal Tes Diagnostik Sepresentasi Grafik Level 3

Soal pada Gambar 2 termasuk soal yang sulit dengan indeks kesulitan butir soal 0,21. Level grafik yang ditampilkan menduduki level 3 fungsi grafik, semua informasi yang diperlukan untuk menjawab soal disajikan pada grafik akan tetapi peserta tes dituntut untuk menginterpretasi dan mengatur kembali informasi yang ada pada grafik. Interpretasi diperlukan untuk menentukan informasi yang dibutuhkan yakni panjang fokus. Penekanan pada prosedur penentuan panjang fokus dari grafik posisi bayangan terhadap posisi objek. Grafik menunjukkan posisi benda $p=30 \mathrm{~cm}$, dan posisi bayangan $i=\infty$. Panjang fokus dapat dihitung dengan memasukkan nilai-nilai yang diperoleh dari grafik ke formula lensa diperoleh $\frac{1}{30}+\frac{1}{\infty}=$ $\frac{1}{f} ; f=30$. Posisi bayangan untuk $p=100 \mathrm{~cm}$ dapat ditentukan dengan menggunakan rumus atau formula lensa $\frac{1}{100}+\frac{1}{i}=\frac{1}{30} ; i=43 \mathrm{~cm}$. Alasan memilih jawaban yang benar adalah saat $\boldsymbol{p}=30 \mathrm{~cm}$ diperoleh panjang fokus lensa $30 \mathrm{~cm}$.

Analisis dari hasil print out program Iteman menunjukkan keberfungsian semua pilihan jawaban dan alasan. Pilihan jawaban "a" dipilih oleh peserta tes sebanyak $18 \%$, pilihan jawaban "b" 45\%, pilihan jawaban "c" $16 \%$ dan pilihan jawaban "d" sebagai jawaban benar dipilih sebanyak $21 \%$. Tingginya prosentase peserta tes memilih jawaban "b" ini menunjukkan belum mampu menginterpretasi grafik dengan layak hanya membaca grafik apa adanya saja seperti yang tertulis. Secara umum dapat dikatakan hampir mendekati $80 \%$ masih salah menafsirkan fungsi grafik level 3. Kesalahan yang 
sama dalam menginterpretasi grafik dilakukan oleh calon guru fisika di negara Turkey sebagaimana dilaporkan oleh Sezen et al (2012), bahkan masih banyak menemukan mahasiswa calon guru fisika yang salah dalam mengkonstruksi grafik fungsi, Kilic dkk (2012) melaporkan hasil penelitian yang sama yakni kemampuan calon guru sains dalam membaca dan menginterpretasi grafik masih tidak memadai, sedangkan kemampuan mengkonstruksi grafik sangat bergantung pada jenis fungsi grafiknya. Data dari tes performa mahasiswa fisika calon guru di tempat penelitian menunjukkan $80 \%$ mampu mengkonstruksi data ke dalam grafik fungsi antara dua variabel dengan benar.

Sumber-sumber kesalahan yang dilakukan oleh peserta tes ditelusuri dari pilihan alasan yang mendasari pilihan jawaban pada bagian pertanyaan soal. Kesalahan dengan persentase terbesar adalah peserta tes tidak dapat menentukan panjang fokus atau jarak fokus berdasarkan data yang disajikan pada grafik. Sebagian besar peserta tes melakukan kesalahan menganalisis grafik bahwa pada jarak objek 30 $\mathrm{cm}$ dengan bayangan objek terletak pada jarak $400 \mathrm{~cm}$, padahal grafik menunjukkan jarak bayangan obyek pada jarak yang amat jauh tidak memotong pada sumbu tegak di $400 \mathrm{~cm}$.

Kemampuan mahasiswa calon guru fisika untuk representasi grafik level 2 tidaklah sama dibandingkan dengan level 3. Rata-rata persentase mahasiswa menyelesaikan soal untuk representasi grafik level 2 sekitar $60 \%$ dapat menjawab dengan benar. Contoh soal untuk representasi grafik level 2 dapat dilihat pada Gambar 3. Grafik pada Gambar 3 menyediakan sebagian informasi yang diperlukan secara langsung dapat diperoleh dari melihat grafik yakni nilai perbesaran bayangan $(m=2)$ dan jarak benda $(p=5)$, kedua nilai ini diperlukan untuk menurunkan panjang fokus untuk dapat menyelesaikan soal.

2. Grafik berikut menyatakan hubungan perbesaran (m) terhadap data jarak obyek (p) dari cermin cekung. Jarak obyek diamati dari $p_{a}=2 \mathrm{~cm}$ sampai $p_{b}=8 \mathrm{~cm}$. Berapakah perbesaran yang dialami obyek saat berada pada jarak $\mathrm{p}=14 \mathrm{~cm}$ dari cermin?
a. $\mathrm{m}=-2,5^{*}$
b. $m=2,5$
c. $\mathrm{m}=-2$
d. $\mathrm{m}=2$

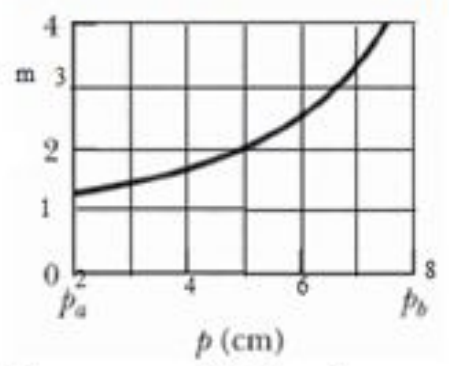

\section{Alasan memilih jawaban:}
a. Perbesaran yang diminta soal dapat langsung diperoleh dari plot titik yang ada di grafik
b. Perbesaran yang ditanya tidak secara langsung diperoleh dari grafik, tetapi melalui perhitungan **
c. Perbesaran dicari dari tangen sudut garis singgung grafik
d. Perbesaran dapat dicari dari persamaan kecenderungan (trend) garis

Gambar 3. Soal Representasi Grafik Level 2 
Tabel 4. Karakteristik Butir Soal Representasi Grafik

\begin{tabular}{cccccccc}
\hline \multicolumn{6}{c}{ Representasi Grafik Untuk Butir Soal pada Tes Konten Optika Geometri } \\
\hline No. & \multicolumn{2}{c}{ Kelas uji coba } & \multicolumn{2}{c}{ Kelas Penelitian } & \multicolumn{2}{c}{ Kelas Bebas } & Level grafik/level \\
butir & TK & DP & TK & DP & TK & DP & Pertanyaan \\
soal & butir & butir & butir & butir & butir & butir & \\
7 & 0,61 & 0,63 & 0,47 & 0,66 & 0,50 & 0,86 & L2/ mudah \\
16 & 0,26 & 0,62 & 0,21 & 0,55 & 0,21 & 1,00 & L3/sulit
\end{tabular}

Representasi Grafik untuk Butir Soal pada Tes Inkuiri Sains Optika Geometri

\begin{tabular}{cccccccl} 
No. & \multicolumn{2}{c}{ Kelas uji coba } & \multicolumn{2}{c}{ Kelas Penelitian } & \multicolumn{2}{c}{ Kelas Bebas } & Level grafik/level \\
butir & TK & DP & TK & DP & TK & DP & Pertanyaan \\
soal & butir & butir & butir & butir & butir & butir & \\
12 & 0,48 & 1,00 & 0,44 & 0,89 & 0,45 & 0,96 & L1/sedang \\
17 & 0,26 & 1,00 & 0,24 & 0,61 & 0,45 & 0,65 & L3/sulit \\
21 & 0.30 & 0,21 & 0,42 & 0,19 & 0,25 & 0,42 & L2/sulit \\
23 & 0,35 & 1,00 & 0,28 & 0,90 & 0,33 & 0,71 & L2/sulit \\
\hline
\end{tabular}

Mahasiswa dituntut mampu menginterpretasi grafik dengan penekanan pada prosedur menentukan jarak fokus berdasarkan grafik hubungan antara perbesaran $(m)$ dengan jarak obyek $(p)$. Grafik menunjukkan nilai $m=2$ dan $p=5$ akan diperoleh jarak bayangan $(q)=-10$ $m$. Nilai ini disubstitusi ke persamaan $\frac{1}{p}+\frac{1}{q}=$ $\frac{1}{f}$ akan diperoleh $f=10 \mathrm{~cm}$. Substitusi nilai $p=14$ akan didapat $q=35$ dan $m=-\frac{q}{p} ; m=$ $-2,5$. Alasan yang benar memilih jawaban adalah perbesaran yang ditanya tidak secara langsung diperoleh dari grafik, tetapi melalui perhitungan. Kesalahan umum yang dilakukan oleh peserta tes tidak dapat menginterpretasi data dari grafik, grafik menunjukkan satu titik ploting yang jelas dapat ditentukan nilai perbesaran dan jarak objek untuk menentukan panjang fokus cermin yang merupakan karakteristik cermin yang spesifik. Peserta tes dituntut mampu melakukan analisis hubungan antar variabel berdasarkan grafik dan menggunakan data hasil analisis dengan formula cermin.

Butir soal representasi grafik untuk inkuiri sains dan konten optika geometri seluruhnya berjumlah 6 butir soal dari 50 butir soal tes diagnostik. Karakteristik sebaran butir soal berdasarkan level fungsi grafik, tipe pertanyaan yang dikembangkan, indeks tingkat kemudahan (TK) dan daya pembeda (DP) butir ditampilkan pada Tabel 4. Berdasarkan Gambar 4 level grafik fungsi memperlihatkan indek tingkat kemudahan butir (TK) representasi grafik L3 < L2 < L1, kelompok grafik level 3 (L3) paling sulit diantara level grafik lainnya.

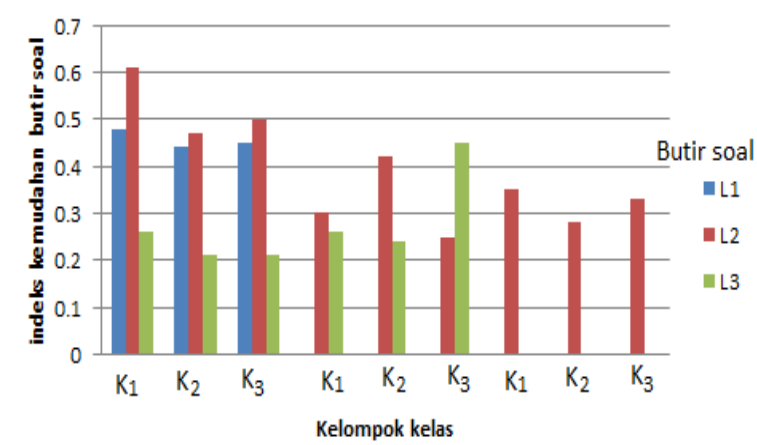

\section{Gambar 4. Indeks Kemudahan Butir Soal Berdasarkan Kelompok Kelas}

Gambar 5 memperlihatkan tingkat persentase keberhasilan peserta tes menjawab dengan benar soal tes diagnostik yang dikembangkan. Rata-rata soal dengan tingkat kesulitan menengah atau sedang seperti butir soal no 12 capaian peserta tes $45 \%$ dapat menjawab soal grafik level 1 dengan benar. Rata-rata jawaban benar peserta tes untuk grafik fungsi level 2 adalah 39\% dan untuk level 3 sebesar 27\%. Kemampuan grafik mahasiswa calon guru fisika untuk level grafik fungsi 1 tidak jauh berbeda dari level 2 dan 3 dengan tingkat kesulitan 
pertanyaan sedang, akan tetapi rata-rata $80 \%$ peserta tes mampu mengerjakan soal representasi grafik mirip level 1 dengan benar pada tes unjuk kerja di laboratorium yakni menampilkan data dalam bentuk grafik, membaca dan menyampaikan informasi secara mudah dan apa adanya yang tidak membutuhkan interpretasi mendalam.

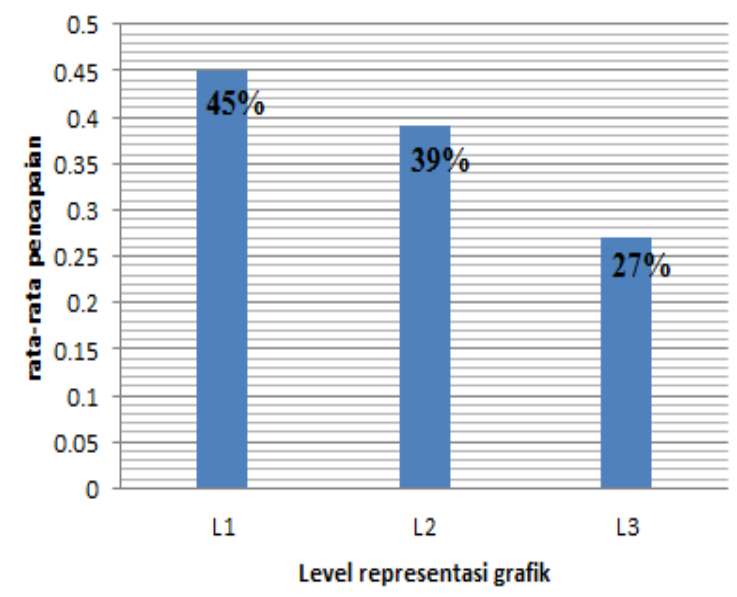

\section{Grafik 5. Pencapaian Kemampuan Rata-rata Berdasarkan Level Grafik Fungsi}

Pembekalan kemampuan penguasaan level-level representasi grafik bagi calon guru harus selalu ditingkatkan di LPTK pencetak calon guru, alasan yang paling mendesak adalah untuk meningkatkan prestasi pendidikan baik tingkat nasional, regional dan internasional. Organisation for Economic Co-operation and Development (OECD) mengembangkan Programme International Student Assessment (PISA) sebagai salah satu ukuran posisi Indonesia pada tahun 2009 menempati urutan ke-61 dari 65 negara peserta (Rosana, 2012). Anagnostopoulou dkk (2012) mencatat soal-soal yang dikembangkan dalam tes PISA dengan konteks yang terintegrasi dengan grafik mencapai $30,8 \%$ dari total soal yang disajikan. Berdasarkan fakta ini masalah pengembangan belajar dan butir soal tes berbasis grafik memerlukan perhatian yang serius.

\section{PENUTUP}

Temuan yang dihasilkan dari penelitian pengembangan tes diagnostik pilihan ganda tiga tingkat terhadap mahasiswa calon guru fisika membuka fakta bahwa penguasaan kemampuan representasi grafik berdasarkan level grafik fungsi masih kurang memadai. Kemampuan untuk mengonstruksi grafik untuk menampilkan sekumpulan data berdasarkan hubungan dua variabel dari hasil tes performa di laboratorium $80 \%$ mampu mengerjakan dengan benar, akan tetapi dengan tes diagnostik pilihan ganda dengan rancangan pertanyaan soal pada tingkat menengah (intermediate) dan tingkat sulit (advanced) untuk grafik fungsi level 1 rata-rata $45 \%$ peserta menjawab dengan benar, untuk grafik fungsi level 2 rata-rata 39\% menjawab dengan benar dan untuk grafik fungsi level 3 rata-rata $27 \%$ peserta tes dapat menjawab dengan benar.

Membelajarkan mahasiswa calon guru fisika bagaimana membaca, menginterpretasi, dan mengkonstruk grafik merupakan suatu topik pembelajaran yang penting dalam materi optika geometri. Kemampuan atau keterampilan di bidang grafik membutuhkan pengetahuan tambahan dari disiplin ilmu matematis dan dapat digunakan untuk disiplin ilmu lainnya. Peningkatan kemampuan di bidang grafik perlu didukung juga dari mata kuliah lainnya sehingga mahasiswa calon guru dapat memeroleh kesempatan belajar yang lebih luas dan mengaplikasikannya.

\section{UCAPAN TERIMA KASIH}

Terima kasih kami ucapkan kepada tiga dosen ahli (Dr. Didi Chandra, Dr. Idah Kaniawati, dan Dr. Anna Ratna Wulan) yang telah memberikan pertimbangan dalam validasi butirbutir soal tes diagnostik. Terima kasih juga diucapkan kepada Ditjen Pendidikan Tinggi yang telah banyak memberikan dukungan dan kepada seluruh Pimpinan Universitas Negeri Medan. Terimakasih kepada Promotor, Kopromotor, dan Anggota Pembimbing Disertasi.

\section{DAFTAR PUSTAKA}

Ainsworth, S. 1999. "The functions of multiple representations". Computers \& Education, 33, hlm.131-152. 
Alkan, F., Erdem, E. 2011. "A Study on Developing Candidate Teachers' Spatial Visualization and Graphing Abilities". Procedia Social and Behavioral Sciences 15, hlm.3446-3450.

Alacaci, C., dkk. 2011. "Pre-Service Elementary Teachers' Understandings of Graphs". Eurasia Journal of Mathematics, Science \& Technology Education, 7(1), hlm.3-14.

Anagnostopoulou, K., Hatzinikita, V., Christidou, V. 2012. "PISA and Biology School Textbooks: the Role of Visual Material". Procedia - Social and Behavioral Sciences, 46, hlm.1839- 1845.

Chang, dkk. 2007. "Investigating Primary and Secondary Students' Learning of Physics Concepts in Taiwan". International Journal of Science Education, 29, (4), hlm. 465-482.

Creswell, J. W., Clark, V. L. P. 2007. Designing and Conducting Mixed Methods Research. California: Sage Publication.

Caleon, I., Subramaniam, R. 2010. "Development and Application of a Three-Tier Diagnostic Test to Assess Secondary Students' Understanding of Waves". International Journal of Science Education, 32, (7) : 939-96.

Dindar, A. C., Geban, O. 2011. "Development of a Three-Tier Test to Assess High School Students' Understanding of Acids and Bases". Procedia Social and Behavioral Sciences, 15 : 600-604.

Galili, I. \& Hazan, A. 2000 . "Learners' Knowledge in Optics: Interpretation, Structure and Analysis". International Journal of Science Education, 22 (1), hlm.57- 88.

Kilic, D., Sezen, N., Sari, M. 2012. "A study of Pre-Service Science Teachers' Graphing Skills". Procedia - Social and Behavioral Sciences, 46.hlm.2937 - 2941.

OECD 2006. Assessing Scientific, Reading and Mathematical Literacy: A Framework for PISA 2006. Paris: OECD.
Parker, J. 2006. "Exploring the Impact of Varying Degrees of Cognitive Conflict in the Generation of Both Subject and Pedagogical Knowledge as Primary Trainee Teachers Learn about Shadow Formation". International Journal of Science Education, 28, (13), hlm.1545-1577.

Rosana, Dadan. 2012. "Menggagas Pendidikan IPA yang Baik Terkait Esensial $21^{\text {st }}$ Century Skills." Makalah, Disampaikan pada Seminar Nasional Pendidikan IPA ke IV, UNESA.

Sezen, N., Uzun, M. S., Bulbul, A. 2012. “An Investigation of preservice Physics Teachers' Use of Graphical Representations" Procedia - Social and Behavioral Sciences 46, hlm.3006 - 3010.

Treagust, D. F., Chandrasegaran, A. L. 2007. "The Taiwan National Science Concept Learning Study in an International Perspective". International Journal of Science Education, 29 ( 4), hlm.391403.

Tsui, C. Y., Treagust, D. 2010. "Evaluating Secondary Students' Scientific Reasoning in Genetics Using a Two-Tier Diagnostic Instrument". International Journal of Science Education, 32 ( 8), hlm.10731098.

Tan, K. C. D, et al. 2005. "The Ionisation Energy Diagnostic Instrument: A Two-Tier Multiple-Choice Instrument to Determine High School Students' Understanding of Ionisation Energy". Chemistry Education Research and Practice, 6, (4), hlm.180197.

Wiji dkk. 2014. "Kemampuan Berpikir Logis dan Model Mental Kimia Sekolah Mahasiswa calon guru". dalam Cakrawala Pendidikan, XXXIII, (1), hlm.147-156.

Yavuz, I., Egin, M. 2010. "First Class High School Students' Behaviour in Non-routine Problems Related to Graphic Representation". Procedia Social and Behavioral Sciences. 2, hlm.2360-2365. 